\title{
RESISTIN - CONCENTRATIONS IN PERSONS WITH TYPE 2 DIABETES MELLITUS AND IN INDIVIDUALS WITH ACUTE INFLAMMATORY DISEASE
}

\author{
David Stejskala, b, Sylva Adamovskáa ${ }^{\text {a Josef Bartek }}$, Renata Jurákováa ${ }^{\text {, Jitka Proškováa }}$ \\ a Department of Laboratory Medicine, Hospital Šternberk \\ ${ }^{b}$ Department of Internal Medicine, Hospital Šternberk \\ ${ }^{c}$ Institute of Medical Chemistry and Biochemistry, Faculty of Medicine, Palacký University, Olomouc
}

Received January 27, 2003; Accepted in revised form July 5, 2003

Key words: Resistin / Leptin / Obesity / Type 2 diabetes mellitus / Inflammation

Resistin is a recently discovered signal molecule, which could help elucidation of the pathophysiology of the insulin resistance and its correlation with obesity. As little information was available about resistin determination in venous blood at the time of our study, we focused on the question whether any correlation exists between persons with type 2 diabetes mellitus, with systemic inflammation, healthy persons and resistin concentrations and laboratory markers of inflammation, peptone, BMI. Differences of resistin values in these types of volunteers were studied as well.

Methods: Persons under study were divided into 3 groups: group A - with clinical signs of inflammatory disease of respiratory tract, leukocytosis $>10000 / \mathrm{ul}$ and CRP concentration $>50 \mathrm{mg} / \mathrm{l}(\mathrm{n}=35)$; group B - with well controlled type 2 DM treated by oral antidiabetic drugs, without clinical signs of inflammation and negative case history of acute disease $(\mathrm{n}=12)$; group $\mathrm{C}$ - without clinical signs of inflammation and negative case history of acute disease $(n=77)$. For all volunteers we determined BMI index and examined resistin, leptin, interleukin 6, TNF-alpha, Na, K, Cl, insulin, cholesterol, HDL-cholesterol, LDL-cholesterol, triacylglycerols, creatinine, uric acid, ALT, AST, GMT, P, Mg and albumin in serum.

Results: Persons with clinical signs of severe inflammation had higher concentrations of Il6, CRP, resistin and a markedly lower BMI, decreased values of glucose, sodium, triacylglycerols, cholesterol, LDL-cholesterol and HDL-cholesterol compared to diabetics of type $2(\mathrm{p}<0.05)$. Persons with clinical signs of severe inflammation showed significantly higher concentrations of TNF-alpha, Il6, CRP, resistin, glucose, leptin and considerably lower values of albumin, sodium and HDL-cholesterol than healthy individuals $(\mathrm{p}<0.05)$. Persons with type 2 DM had markedly higher values of BMI, CRP, glucose, triacylglycerols, LDL-cholesterol, GMT and leptin, compared to healthy volunteers $(\mathrm{p}<0.05)$. None of the three groups differed markedly in age or sex.

Healthy volunteers show a significant correlation between leptin and resistin (correlation coefficient 0.82 ); this correlation was not found in patients with inflammation and type $2 \mathrm{DM}$. The group of volunteers with inflammations was found to have a significant positive correlation between resistin and inflammatory markers (correlation coefficient $0.3-0.5$ ), negative correlation between resistin and cholesterol. We also found positive correlations between leptin and BMI as well as negative correlations between leptin and CRP. No significant correlations between resistin and other studied parameters were found in persons with type $2 \mathrm{DM}$.

Conclusion: In healthy population a correlation was found between leptin and resistin concentrations in serum. In patients with severe inflammatory disease a correlation between resistin concentration and laboratory markers of inflammation was shown, however, no correlation was found between leptin and resistin. Resistin concentration in the serum of these patients is significantly higher $(\mathrm{p}<0.01)$ compared to healthy subjects and well controlled persons with type $2 \mathrm{DM}$ with signs of insulin resistance. This may be due to a direct effect of inflammatory cytokines on resistin production. In persons with type $2 \mathrm{DM}$ no significant correlations were found between resistin and other individual parameters ( insulin sensitivity markers, BMI or leptin). Resistin concentrations in persons with type 2 DM do not differ from concentrations of common population.

\section{INTRODUCTION}

The prevalence of type 2 diabetes mellitus reaches 5-6\%. Its relation to obesity is well known (up to $80 \%$ of cases). Individuals with type 2 DM mostly show a relative lack of insulin caused by insulin resistance (reduced utilization of glucose in muscles and fat) and lower ability to inhibit gluconeogenesis in liver.

Similarly, obesity is characterized by insulin resistance and increased supply of triacylglycerols in adipose tissue. All these problems are of practical clinical importance ${ }^{4,20}$. In both cases it has not been explained until 
now whether fat storage into adipocytes results in insulin resistance in muscles, liver and other tissues.

Resistin (in addition to leptin and TNF-alpha) seems to be one of promising parameters that could help to elucidate pathophysiology of the origin of insulin resistance and its association with obesity. These parameters have been studied intensively in animal experiments. However, resistin and leptin and TNF-alpha pathophysiology in human seems to be quite different.

With regard to the fact that at the time of our study sporadic information was available about resistin determination in venous blood, we decided to investigate the resistin values and answer the following questions:

1. Persons with sever systemic inflammation

a) Does any correlation exist between resistin concentration and inflammation markers?

b) Does any relationship exist between the concentration of resistin, leptin and BMI?

c) Do resistin values differ from resistin values in the normal population?
2. Persons with type $2 \mathrm{DM}$ treated with oral antidiabetic drugs

a) Does any correlation exist between insulin sensitivity markers (HOMA) and resistin concentration?

b) Does any correlation exist between BMI and resistin concentration?

c) Do resistin values differ from resistin values in the normal population?

\section{METHODS}

Persons under study were divided into 3 groups according to the following criteria:

- Group A with clinical signs of inflammatory disease of respiratory tract (bronchitis, bronchopneumonia, pneumonia), leukocytosis $>10000 / \mu$ l and CRP concentration $>50 \mathrm{mg} / \mathrm{l}$ (35 persons).

- Group B with well controlled type 2 DM treated by oral antidiabetic drugs (HbA1c $<7 \%)$, without clini-

Table 1. Basic statistical characteristics of parameters in three groups of volunteers.

\begin{tabular}{|c|c|c|c|c|c|c|c|c|c|}
\hline & 2 type DM & $\mathrm{n}=12$ & & $\begin{array}{l}\text { Inflam } \\
\text { mation }\end{array}$ & $\mathrm{n}=35$ & & Healthy & $\mathrm{n}=77$ & \\
\hline Parameter & Mean & Median & SD & Mean & Median & SD & Mean & Median & $\mathrm{SD}$ \\
\hline Sex - male & 7 & - & - & 19 & - & - & 35 & - & - \\
\hline Sex - female & 5 & - & - & 16 & - & - & 42 & - & - \\
\hline Age (years) & 63.8 & 64.5 & 9.1 & 58.9 & 67.0 & 26.0 & 62.2 & 62.0 & 17.3 \\
\hline CRP (mg/l) & 5.3 & 3.6 & 4.4 & 107.2 & 81.0 & 52.0 & 0.6 & 0.7 & 0.4 \\
\hline Glucose (mmol/l) & 8.2 & 7.2 & 2.4 & 6.3 & 5.0 & 2.6 & 4.8 & 4.9 & 1.0 \\
\hline Resistin (ng/ml) & 21.4 & 18.4 & 9.1 & 61.4 & 56.0 & 30.0 & 20. & 16.6 & 7.1 \\
\hline BMI & 30.2 & 30.2 & 5.3 & 24.7 & 24.0 & 5.9 & 25.3 & 25.1 & 3.7 \\
\hline $\mathrm{Na}(\mathrm{mmol} / \mathrm{l})$ & 138.7 & 138.5 & 2.0 & 135.7 & 136.0 & 3.1 & 140.1 & 140.7 & 2.1 \\
\hline $\mathrm{K}(\mathrm{mmol} / \mathrm{l})$ & 4.6 & 4.6 & 0.3 & 4.2 & 4.0 & 0.6 & 4.2 & 4.1 & 0.4 \\
\hline $\mathrm{Cl}(\mathrm{mmol} / \mathrm{l})$ & 104.7 & 104.0 & 2.4 & 104.5 & 105.0 & 3.8 & 105.0 & 105.0 & 2.1 \\
\hline Insulin (UI/ml) & 16.6 & 17.1 & 9.4 & 13.7 & 8.1 & 21.7 & 8.0 & 7.0 & 4.3 \\
\hline $\begin{array}{l}\text { TNF-alpha } \\
(\mathrm{pg} / \mathrm{ml})\end{array}$ & 6.8 & 5.7 & 3.2 & 8.1 & 7.0 & 4.7 & 5.2 & 4.9 & 3.8 \\
\hline $\mathrm{Il} 6(\mathrm{pg} / \mathrm{ml})$ & 5.0 & 5.0 & 0.0 & 46.6 & 25.0 & 84.1 & 5.0 & 5.0 & 0.0 \\
\hline Chol (mmol/l) & 5.4 & 5.3 & 0.7 & 3.9 & 4.0 & 1.0 & 4.4 & 3.7 & 1.3 \\
\hline HDL (mmol/l) & 1.4 & 1.3 & 0.2 & 1.0 & 1.0 & 0.3 & 1.5 & 1.5 & 0.3 \\
\hline $\operatorname{Trg}(\mathrm{mmol} / \mathrm{l})$ & 2.3 & 2.0 & 1.3 & 1.4 & 1.0 & 0.5 & 1.1 & 1.0 & 0.4 \\
\hline $\mathrm{LDL}(\mathrm{mmol} / \mathrm{l})$ & 3.7 & 3.8 & 0.4 & 2.5 & 3.0 & 0.9 & 2.8 & 2.6 & 1.0 \\
\hline UA (umol/l) & 313.0 & 78.9 & 78.9 & 285.0 & 268.0 & 107.0 & 281.0 & 288.0 & 63.0 \\
\hline ALT (ukat/l) & 0.6 & 0.4 & 0.4 & 0.3 & 0.3 & 0.6 & 0.4 & 0.3 & 0.2 \\
\hline AST (ukat/l) & 0.5 & 0.4 & 0.2 & 0.7 & 0.6 & 1.0 & 0.4 & 0.4 & 0.1 \\
\hline GMT (ukat/l) & 1.2 & 0.6 & 1.2 & 1.0 & 1.0 & 1.1 & 0.3 & 0.2 & 0.1 \\
\hline Creatinine & & & & & & & & & \\
\hline (umol/1) & 94.4 & 95.5 & 16.6 & 107.1 & 93.5 & 70.5 & 95.0 & 92.0 & 12.0 \\
\hline Albumin (g/l) & 41.6 & 42.1 & 1.9 & 33.8 & 32.0 & 17.6 & 46.3 & 44.9 & 3.1 \\
\hline $\mathrm{Mg}(\mathrm{mmol} / \mathrm{l})$ & 0.9 & 0.9 & 0.1 & 1.0 & 1.0 & 0.0 & 0.9 & 0.9 & 0.1 \\
\hline $\mathrm{P}(\mathrm{mmol} / \mathrm{l})$ & 1.1 & 1.1 & 0.2 & 1.1 & 1.0 & 0.1 & 1.3 & 1.2 & 0.5 \\
\hline Leptin (ng/ml) & 20.5 & 13.2 & 16.5 & 15.2 & 9.2 & 7.8 & 5.1 & 1.8 & 5.8 \\
\hline Leptin/resistin & 1.1 & 1.0 & 0.3 & 0.4 & 0.3 & 0.3 & 0.2 & 0.3 & 0.3 \\
\hline Resistin/CRP & 7 & 5 & 2.7 & 0.6 & 0.6 & 0.4 & 59.9 & 34 & 21.0 \\
\hline
\end{tabular}

SD standard deviation 
cal signs of inflammation and with negative history of acute disease (12 persons)

- Group $\mathrm{C}$ without clinical signs of inflammation and with a negative history of acute disease ( 77 persons)

All volunteers were examined for the following parameters:

Resistin (ELISA, MARC-Biovendor. CV-series - 6.1\%), leptin (ELISA, MARC-Biovendor), CRP (LEIA, Immulite-DPC), Interleukin-6 (LEIA, Immulite2000 $D P C)$, TNF-alpha (LEIA, Immulite2000-DPC), Na, K, $\mathrm{Cl}$ (ISE, Ilab600), creatinine (Jaffe, Ilab600), uric acid (enzyme, Ilab600-Biovendor), ALT (enzyme, Ilab600-Biovendor), AST (enzyme, Ilab600-Biovendor), GMT (enzyme, Ilab600-Biovendor) P (Ilab600, Biovendor), Mg (Ilab600, Skalab), cholesterol (enzyme, Ilab600-Biovendor), HDL cholesterol (direct method, Ilab600-Biovendor), LDL cholesterol (direct method, Ilab600-Biovendor), triacylglycerols (enzyme, Ilab600-Biovendor), insulin (LEIA, Immulite2000 - DPC), albumin (Ilab600, Biovendor). Blood was taken between $6^{\circ o}-9^{\circ o}$ a.m. following the overnight fasting. The routine biochemical analyses were performed on the day of serum separation. Serum samples for special analyses resistin and leptin were stored at $-80{ }^{\circ} \mathrm{C}$ in separated aliquots, usually for less than one month.
BMI was determined in all probands.

All data were processed statistically using Stagrafics 6.0 ANOVA.

\section{RESULTS}

We examined 114 persons and divided them into 3 groups.

Persons with clinical signs of severe inflammation (Group $A$ ) had significantly higher serum concentrations of Il6, CRP, resistin and significantly lower BMI, lower values of glucose, sodium, triacylglycerols, cholesterol, LDL-cholesterol, HDL-cholesterol and indexes leptin/resistin as well as resistin/CRP indexes than diabetics of type 2 (Group B) (Tables 1,2$)$.

Persons with clinical signs of severe inflammation (Group $A$ ) had significantly higher concentrations of TNF-alpha, Il6, CRP, resistin, glucose, leptin, and considerably lower values of albumin, sodium, HDL-cholesterol and resistin/CRP index compared to healthy volunteers (Group $C$ ).

Our patients with signs of severe inflammation (Group $A$ ) can be characterized as persons with a significant increase in inflammatory markers, catabolism with hypocholesterolemia and hypoalbuminemia (Tables 1, 2).

Table 2. Significance of difference of individual parametersbetween the groups A, B, C.

(Post hoc tests, multiple comparisons).

\begin{tabular}{|c|c|c|c|}
\hline Parameter & $\begin{array}{c}\text { Inflammation-DM } \\
\text { A vs B }\end{array}$ & $\begin{array}{c}\text { Inflammation-Healthy } \\
\text { A vs C } \\
\end{array}$ & $\begin{array}{l}\text { DM-Healthy } \\
\text { B vs C }\end{array}$ \\
\hline CRP & $* *$ & $* *$ & $* *$ \\
\hline Glucose & $* *$ & ** & $* *$ \\
\hline Resistin & ** & ** & NS \\
\hline BMI & * & NS & NS \\
\hline $\mathrm{Na}$ & $* *$ & $* *$ & NS \\
\hline K & NS & NS & NS \\
\hline $\mathrm{Cl}$ & NS & NS & NS \\
\hline Insulin & NS & NS & NS \\
\hline TNF-alfa & NS & * & NS \\
\hline Il6 & $* *$ & $* *$ & NS \\
\hline Chol & $* *$ & NS & NS \\
\hline HDL & $* *$ & ** & NS \\
\hline Trg & $* *$ & NS & $* *$ \\
\hline LDL & $* *$ & NS & $* *$ \\
\hline UA & NS & NS & NS \\
\hline ALT & NS & NS & NS \\
\hline AST & NS & NS & NS \\
\hline GMT & NS & NS & $* *$ \\
\hline Creatinine & NS & NS & NS \\
\hline Albumin & NS & $* *$ & NS \\
\hline $\mathrm{Mg}$ & NS & NS & NS \\
\hline $\mathrm{P}$ & NS & NS & NS \\
\hline Leptin & NS & ** & ** \\
\hline Leptin/Resistin & $* *$ & NS & $* *$ \\
\hline Resistin/CRP & ** & $* *$ & ** \\
\hline
\end{tabular}

$* * \mathrm{p}<0.01 \mathrm{NS} \mathrm{p}>0.05 * \mathrm{p}<0.05$ 
Individuals with type 2 DM (Group B) had significantly higher values of BMI, CRP, glucose, triacylglycerols, LDL-cholesterol, GMT, leptin, leptin/resistin index, and lower values of resistin/CRP index compared to healthy volunteers (Group $C$ ).

Our patients with type $2 \mathrm{DM}$ can be characterized as persons with obesity, hyperinsulinemia, atherogenic lipid phenotype (Tables 1,2).
Healthy volunteers (Group C) had no signs of DM, lipid metabolic disorders, impaired function of kidney, liver, inflammation signs or another severe disease on the basis of their case history, clinical and laboratory examinations (Tables 1,2).

None of the three groups differed significantly in age or sex (Tables 1, 2, 3).

Table 3. Significant correlations in the whole group under study.

\begin{tabular}{|c|c|c|c|c|}
\hline Parameter & Whole group & Inflammation & 2 type DM & Healthy \\
\hline Resistin & $\begin{array}{l}\text { CRP }(0.59) \\
\text { Na }(-0.42) \\
\text { TNF-alpha }(0.34) \\
\text { IL6 }(0.37) \\
\text { Chol }(-0.43) \\
\text { HDL }(-0.46) \\
\text { LDL }(-0.36) \\
\text { Albumin }(-0.4) \\
\text { Creatinine }(0.28)\end{array}$ & $\begin{array}{l}\text { Kalium }(0.35) \\
\text { Chol }(-0.35) \\
\text { TNF-alpha }(0.32) \\
\text { CRP }(0.5)\end{array}$ & & Leptin (0.82) \\
\hline CRP & $\begin{array}{l}\text { IL6 }(0.58) \\
\text { Chol }(-0.36) \\
\text { HDL }(-0.6) \\
\text { Albumin }(-0.8) \\
\text { Resistin }(0.59) \\
\text { LDL }(-0.38)\end{array}$ & $\begin{array}{l}\text { IL6 }(0.47) \\
\text { Chol }(-0.41) \\
\text { LDL }(-0.35) \\
\text { P }(-0.51) \\
\text { Leptin }(-0.34)\end{array}$ & Leptin (0.7) & \\
\hline Leptin/Resistin & \begin{tabular}{|l} 
BMI $(0.6)$ \\
$\operatorname{Trg}(0.56)$ \\
$\operatorname{LDL}(0.37)$ \\
\end{tabular} & & & \\
\hline Leptin & $\begin{array}{l}\text { BMI (0.54) } \\
\text { Trg }(0.51)\end{array}$ & $\begin{array}{l}\text { CRP }(-0.34) \\
\text { BMI }(0.47)\end{array}$ & $\begin{array}{l}\text { CRP }(0.7) \\
\text { Glucose }(-0.34) \\
\mathrm{Cl}(0.46) \\
\mathrm{Il} 6(0.38)\end{array}$ & $\begin{array}{l}\text { Chol (0.82) } \\
\operatorname{Mg}(0.8)\end{array}$ \\
\hline & & & $\operatorname{BMI}(0.76)$ & \\
\hline Insulin & HDL $(-0.39)$ & $\begin{array}{l}\text { HDL }(-0.48) \\
\mathrm{P}(0.35)\end{array}$ & HDL $(-0.74)$ & \\
\hline $\mathrm{Il6}$ & LDL $(-0.3)$ & CRP $(0.47)$ & & \\
\hline Albumin & HDL $(0.3)$ & & & \\
\hline BMI & $\operatorname{Trg}(0.51)$ & $\begin{array}{l}\operatorname{Trg}(0.35) \\
\text { UA }(0.48) \\
\text { Leptin }(0.48)\end{array}$ & $\begin{array}{l}\operatorname{Trg}(0.68) \\
\text { Leptin }(0.76) \\
\text { Glucose }(0.85)\end{array}$ & \\
\hline $\operatorname{Trg}$ & LDL $(0.35)$ & $\mathrm{P}(0.36)$ & $\mathrm{P}(-0.51)$ & \\
\hline Resistin/CRP & HDL $(0.38)$ & & & \\
\hline \multirow[t]{2}{*}{ TNF alpha } & & chol $(-0.63)$ & $\mathrm{Cl}(0.75)$ & \\
\hline & & $\begin{array}{l}\text { HDL }(-0.37) \\
\text { LDL }(-0.5) \\
\text { Glucose }(-0.34) \\
\mathrm{Cl}(0.46) \\
\mathrm{Il} 6(0.38)\end{array}$ & $\begin{array}{l}\text { Creatinine }(0.8) \\
\text { Albumin }(-0.75)\end{array}$ & \\
\hline Glucose & & $\begin{array}{l}\text { Insulin }(0.54) \\
\text { TNF-alpha }(-0.34) \\
\text { LDL }(0.36) \\
\text { ALT }(0.38) \\
\end{array}$ & $\begin{array}{l}\text { BMI }(0.85) \\
\operatorname{Mg}(-0.78)\end{array}$ & \\
\hline
\end{tabular}


When investigating a relationship between resistin concentration and other individual parameters, we found in the whole group significant positive correlations with the values of CRP, IL6, TNF-alpha and creatinine, and negative correlations with the values of cholesterol and albumin. No correlation was found between resistin and leptin, resistin and BMI (Table 3).

Healthy volunteers (Group $C$ ) showed a significant correlation between leptin and resistin; this correlation was not found in patients with inflammation or type 2 DM. This group also showed a distinct correlation between leptin and concentrations of cholesterol, magnesium and BMI (Table 3). The group of volunteers with inflammation (Group $A$ ) was found to have a significant positive correlation between resistin and inflammatory markers, kalemia, and a negative correlation between resistin and cholesterol. We also recorded positive correlations between leptin and BMI and negative correlations between leptin and CRP (Table 3).

In persons with type $2 \mathrm{DM}$ (Group B) no significant correlations between resistin and other measured parameters were found. We recorded a distinct positive correlation between leptin and CRP, Il-6 and BMI, and a negative correlation between leptin and glucose in serum (Table 3).

\section{DISCUSSION}

Several years ago, a new signal molecule was discovered and termed resistin $(12,5 \mathrm{kDa}$, according to its effect on insulin resistance). Resistin is a product of RSTN gene that belongs to the category of proteins rich in cysteine; proteins in this category comprise, due to a high homology they are confused: ADSF (Adipose Tissue-Specific Secretory Factor), FIZZ3 (Found in Inflammatory Zone), FIZZ1 (identified for the first time in a bronchoalveolar lavage of the inflammation-altered liver), FIZZ2, RELM-a, RELM-b (resistin like molecule).

Resistin is produced by preadipocytes and adipocytes in the form of a propeptide (108 amino acids); prior to secretion into circulation, it liberates a hydrophobic signal peptide (16 amino acids). Then resistin circulates in the system circulation as a dimer consisting of 92 amino acids, connected by disulfide bridges (mice resistin consists of 114 amino acids).

Occurrence and effects: resistin and resistin-like molecules occur in white adipose tissue, mammary glands, heart, brain, lungs, gastrointestinal tract (it was found that e.g. RELM-b was present in gastrointestinal tract in the are of a high proliferation activity of epithelia, was excessively expressed near tumors - it is supposed to influence proliferation).

With regard to a high homology between RELM and FIZZ it is believed that the effect of both substances is similar.
Pathophysiology of resistin - mice models:

1. Resistin reduces the insulin-stimulated uptake of glucose by tissues, reduces their insulin sensitivity (it is agonist of insulin effect). It probably influences probably myocytes of striated muscles, hepatocytes and adipocytes (effect on myocytes, hepatocytes and CNS cells has not been verified yet). Resistin expression in adipocytes is high.

2. Resistin is involved in the origin of some types of obesity. Simply said: resistin induces obesity (resistin expreses in abdominal adipose tissue in mice is significantly higher than in other parts of adipose deposits) ${ }^{22,17,15,14}$.

3. High values of mRNA resistin are reduced after administration of thiazolindion (TZD) and after a prolonged fasting. However, TZD reduce mRNA resistin only in obese mice (in thin mice they increase resistin expression - verified on various adipocyte lines?.

4. Resistin is more expressed during differentiation of adipocytes affected by feedback (decreases adipogenesis $)^{23}$.

5. Resistin is probably involved in maturation of the organism (at birth its expression is low, increases after 14 days, decreases with maturation of hypopituitary axis) and in metabolic control of lactation (decrease in expression in adipose tissue at lactation together with leptin expression $)^{2}$.

6. FIZZ molecules are more expressed in allergies or inflammatory diseases (e.g. elevated expression of FIZZ1 is associated with pneumonia). It is assumed that resistin plays a similar role in inflammatory disease related to obesity (obesity is associated with local overproduction of inflammatory cytokines, endothelial dysfunction, etc. $)^{11}$. This is supported by the fact that TZD reduces local production of TNF-a in adipocytes.

Pathophysiology of resistin - human study:

It has not been proved yet whether the above-mentioned relations apply also to human.

1. Resistin expression in adipocytes is low, resistin mostly occurs in mononuclear cells.

2. Differentation of adipocytes is related to decreased resistin expression (reverse effect in mice).

3. Obesity and insulin sensitivity disorder is associated with polymorphism of resistin gene (but no correlation was proved between type $2 \mathrm{DM}$ and gene polymorphism) and obese people have an elevated resistin expression in abdominal adipose tissue (this could indicate relation between resistin and obesity in type $2 \mathrm{DM}$ or risk of IHD), but clinical studies have not proved yet any correlation between resistin gene expression, insulin sensitivity and type $2 \mathrm{DM}^{15,10,14,16,7}$.

4. It has not been proved yet that a relation between adipocytes and insulin effect is mediated by TNF-a or resistin ${ }^{10}$. 
Regulation: Resistin expression is regulated by many hormones and cytokines related to the metabolism of insulin, glucose and adipocyte metabolism in general. Increase: hyperglycemia, hypercortisolism (administration of dexamethasons to mice resulted in elevation of mRNA resistin $2.5-3.5 \times$ ).

Decrease: GH deficiency (application of GH leads to normalization - increased resistin expression), insulin (insulin is considered to be the main inhibitor of resistin), thiazolindions (effect via PPAr-g (peroxisome proliferator-activated receptor-g). However, TZD decrease mRNA resistin only in obese mice, in thin mice they increase resistin expression - verified on various adipocyte lines), TNF-alpha (up by $80 \%$ ), adrenalin, androgens, endothelin- $1^{17,5,13,1,2,9}$. Expression of resistin in adipose tissue also decreases at lactation (together with leptin expression $)^{17}$.

Measurement of resistin concentration: Most studies did not investigate resistin concentration in serum? ${ }^{7}$. A validated diagnostic set for resistin determination was not available at the time of our study; we found only one producer of the diagnostic set for resistin determination, which did not meet the analytical criteria ${ }^{7}$.

Analytical characteristics of the set used in this study are commonly used.

In our previous study, resistin concentration ranged from 7.3 to $21.3 \mathrm{ng} / \mathrm{ml}(\mathrm{x} \pm 2 \mathrm{~s})$ in 123 healthy volunteers without obesity. No correlation was proved between resistin and age, sex or BMI. The values of resistin in healthy probands under the present study (Group $C$ ) did not differ from those recorded previously ${ }^{18}$.

With regard to the fact that a correlation was found between the concentrations of resistin and leptin in healthy probands (which we did not find in diabetics and persons with severe systemic inflammation), we assume that in healthy individuals there exists a metabolic regulation in which both factors are involved ${ }^{14}$.

Persons with inflammation (Group $A$ ) can be characterized as probands with significant increase in inflammatory markers and catabolism.

Increased resistin values found in those persons (compared to values in normal population) could be caused by a local effect of inflammatory cytokines on its production (FIZZ analogy) ${ }^{11}$.

It is interesting that in the case of severe inflammation, correlation between leptin and resistin concentrations disappears in contrast to healthy individuals where it is present (probably an effect of cytokines).

Persons with type $2 \mathrm{DM}$ are used to develope on atherogenic lipotype, signs of chronic inflammation and a higher risk of atherosclerotic complications. This observation corresponds with our Group B. In these probands the correlation between inflammation markers and resistin concentrations disappers. Persons with type $2 \mathrm{DM}$ have higher CRP concentrations than healthy individuals, but cytokine values are not significantly increased in systemic circulation. This fact may account for no relations between inflammatory markers and resistin concentration observed in acute severe inflammation. It is probable that a "slight" chronic inflammation (e.g. endothelial dysfunction) does not influence significantly resistin concentrations.

Determination of a limits of resistin concentration in human population could answer many questions related to the origin of insulin resistance, despite the fact that resistin function in human still remains unclear (in contract to mice models).

It has not been proved yet that correlation between insulin resistance and resistin exists in humans. Among other questions that should be answered is the existence of the resistin receptor and its location (muscles, brain, liver, etc.).

The analogy between human and mice resistin is not adequate (about 60\%); this stimulates further questions and indicates a low stage of sequence similarity among species $^{8}$.

\section{CONCLUSION}

We confirmed the existence of a correlation between leptin and resistin concentrations in the serum of a healthy population.

In patients with severe inflammatory disease we found a correlation between resistin concentration in serum and laboratory markers of inflammation (CRP, TNF-alpha, IL6), however, no correlation was found between leptin and resistin.

Resistin concentration in the serum of these patients is significantly higher than in healthy population or in well controlled persons with type $2 \mathrm{DM}$ with signs of insulin resistance. This may be probably explained by a direct effect of inflammatory cytokines on resistin production.

In patients with type $2 \mathrm{DM}$ we found no significant correlations between resistin, insulin sensitivity markers, BMI or leptin. Resistin concentration in patients with type $2 \mathrm{DM}$ does not differ from resistin concentrations of a common population.

\section{AKNOWLEDGEMENT}

This study was supported by grant MSM 151100003 from the Ministry of Youth and Education of the Czech Republic.

\section{REFERENCES}

1. Bastard JP, Maachi M, Van Nhieu JT, Jardel C, Bruckert E, Grimaldi A, Robert JJ, Capeau J, Hainque B. (2002) Adipose Tissue IL-6 Content Correlates with Resistance to Insulin Activation of Glucose Uptake both in vivo and in vitro. J Clin Endocrinol Metab 87, 2084-2089. 
2. Bing C, Gomez-Ambrosi J, Zabalegui N, Williams G. (2002) Resistin and RELM-a gene expression in white adipose tissue of lactating mice. Bioch Biop Res Commun, 296, 458-462.

3. Blagoev B, Kratchmarova I, Mogens M, Nielsen MM, Fernandez MM. Inhibition of adipocyte differentiation by Resistin like molecule. JBC Papers in press. Published on August 19, 2002 as Manuscript.

4. Chlup R, Vaverková H, Bartek J. (1997) Complementary insulin therapy improves blood glucose and serum lipid parameters in type 2 (non-insulin-dependent) diabetic patients. I. Effects on blood glucose control. Exp Clin Endocrinol Diabetes 105 (Suppl 2), 70-73.

5. Delhanty JP, Mesotten D, McDougall F, Barter RC. (2002) Growth Hormone Rapidly Induces Resistin Gene Expression in White Adipose Tissue of Spontaneous Dwarf (SDR) Rats. Endocrinology 143, 2445-2448.

6. Dietze D, Koenen M, Rohrig K, Horikoshi H. (2002) Impairment of Insulin Signaling in Human Skeletal Muscle Cells by Co-Culture With Human Adipocytes. Diabetes 51, 2369-2376.

7. http://www.phoenixpeptide.com/Catalog\%20Files/Resistin/resistin. htm.

8. Flier JS. (2001) The missing link with obesity? Nature, 292, 409.

9. Fukui Y, Motojima K. ( 2002) Expression of resistin in the adipose tissue is modulace by various factors. Diabet Obes Metab 4, 341-350.

10. Janke J, Engeli S, Gorzelniak K, Luft FC, Sharma AM. (2002) Resistin gene expression in human adipocytes is not related to insulin resistance. Obes Res 10, 1-5.

11. Gomez-Ambrosi J. (2001) Do Resistin and Resistin-Like Molecules Also Link Obesity to Inflammatory Diseases? Annals of Internal Medicine 4, 306-307.

12. Li J, Yu X, Pan W, Unger RH. (2002) Gene expression profile of rat adipose tissue at the onset of high-fat-diet obesity. Am J Physio Endocrinol Metab 282, 1334-1341.

13. Ling C, Kindblom J, Wennbo H, Billig H. (2001) Increased resistin expression in the adipose tissue of male prolactin transgenic mice and in male mice with elevated androgen levels. FEBS Lett 26, $147-150$.

14. McTernan CL, McTernan PG, Harte AL, Levick PL, Barnett AH, Kumar S. (2002) Resistin, central obesity, and type 2 diabetes. Lancet 359, 46-47.

15. McTernan PG, McTernan CL, Chetty R, Jenner K, Fisher FM, Lauer MN, Crocker J, Barnett AH, Kumar S. (2002) Increased resistin gene and protein expression in human abdominal adipose tissue. J Clin Endocrinol Metab 87, 2407.

16. Nagaev I, Smith U. (2001) Insulin resistance and type 2 diabetes are not related to resistin expression in human fat cells or skeletal muscle. Biochem Biophys Res Commun 285, 561-564.

17. Shojima N, Sakoda H, Ogihara T, Fujishiro M. (2002) Humoral regulation of resistin expression in 3T3-L1 mouse adipose. Diabetes $51,1737-1744$.

18. Stejskal D, Růžička V, Bartek J. ( 2002) Preliminary experience with resistin assessment in common population. Biomed $\mathrm{Pa}$ pers 146, 47-49.

19. Stepan CM, Bailey TB, Bhat S, Brownb EJ. (2001) The hormone resistin links obesity to diabetes. Nature 409, 307-308.

20. Vaverková H, Chlup R, Ficker L, Novotný D, Bartek J. (1997) Complemetary insulin therapy improves blood glucose and serum lipid parameters in type 2 (non-insulin-dependent) diabetic patients: II. Effects on serum lipids, lipoproteins and apoproteins. Exp Clin Endocrinol Diabetes 105 (Suppl 2), 74-77.

21. Vidal-Puik A. (2001) Resistin. Clinical Endocrinology, 55, 437-438.

22. Wang H, Chu WS, Hemphill C, Elbein SC. (2002) Human Resistin Gene: Molecular Scanning and Evaluation of Association with Insulin Sensitivity and Type 2 Diabetes in Caucasians. J Clin Endocrinol Metab 87, 2520-2524.

23. Way JM, Gorgun CZ, Tong Q, Uysal KT, Brown KK, Harrington WW, Oliver WR Jr, Willson TM, Kliewer SA, Hotamisligil GS. (2001) Adipose tissue resistin expression is severely suppressed in obesity and stimulated by peroxisome proliferator-activated receptor gamma agonists. J Biol Chem 276, 25651-25653. 